\title{
THE TREATMENT OF VITREORETINAL SCAR TISSUE
}

\author{
PETER K. LEAVER \\ London
}

\begin{abstract}
SUMMARY
Methods of treating vitreoretinal scarring have been transformed by the introduction and development of closed intraocular microsurgery. Controlled access to the posterior segment of the eye, under excellent conditions for intraoperative viewing, have increased our understanding of the pathophysiology of epiretinal membranes. The ready ability to harvest tissue specimens for histopathological and immunochemical study, enabled by this type of surgery, has provided the stimulus for much basic research into the nature of fibrocellular (and fibrovascular) proliferative disease. Treatment of retinal conditions characterised by the proliferation of fibrocellular membranes has been improved, but the most important future advances are likely to be made in the fields of molecular biology and pharmacology.
\end{abstract}

\section{BACKGROUND}

When Jules Gonin first proposed that retinal detachment occurs as a result of breaks in the retina, ' advanced surgical technology was not available. He and his successors in the field of retinal surgery had no way of treating the breaks directly, from within the eye, as they had no means of gaining access to them. They therefore had no choice other than to create an adhesion between the tissues surrounding the break(s), rather than attempt to repair the retinal defect(s) themselves. ${ }^{2-4}$

Remarkably, in spite of technological advances enabling access to the retina, especially during the past 20 years, ${ }^{5.6}$ as well as experimental work on glues ${ }^{7.8}$ and patches, ${ }^{9}$ there is still no satisfactory method of repairing breaks in the retina. Broadly speaking, the methods adopted by Gonin and his followers are still in use today. Thermocautery ${ }^{10}$ gave way to diathermy ${ }^{11}$ and diathermy to cryotherapy, ${ }^{12}$ sunlight ${ }^{1.3}$ has yielded to the laser tube $e^{1+.15}$ and scleral resection, ${ }^{16}$ and the supramid suture ${ }^{17}$ has been superseded by silastic sponges ${ }^{18}$ and solid silicone explants, ${ }^{19}$ but the general principles of repair remain the same.

Considering that the retina is supported by a glial net-

Correspondence to: P. K. Leaver, FRCS, FRCOphth, Moorfields Eye Hospital, City Road, London EC1V 2PD, UK. work, and proliferation of retinal glia forms the basis of most epiretinal membranes, ${ }^{20-23}$ one might think that spontaneous repair of retinal breaks would occur as a matter of course. This is, however, not the case and spontaneous closure of breaks with consequent retinal reattachment, although by no means rare, is not a common event. Dehiscences in the retina do not usually heal over. Persistent traction on the torn retina, by the attached vitreous gel, commonly distorts and enlarges retinal tears, discouraging healing. Although successful attempts to induce healing in macular holes, by removing the vitreous and applying growth factor directly to the retina, have recently been reported, ${ }^{2+}$ this technique is not yet widely available or tested; nor is it necessarily applicable to peripheral tears. The mechanism employed by Gonin - bringing the retina into apposition with the underlying tissues and inducing a scar to form between them and the edges of the break - is, in consequence, still in use today.

Recent advances in our understanding and treatment of retinal detachment relate not only to the closure of breaks per se, but to the secondary effects generated by the healing process, in particular the stimulation of scar formation, inherent in the surgical method. Thus, modern techniques of closed intraocular microsurgery have focussed on the removal of epiretinal membranes and internal tamponade of retinal breaks in proliferative vitreoretinopathy (PVR), a condition which commonly results from overexuberance of the repair process and is often made worse by retinal reattachment surgery.

It is the ability to access intraocular structures, aided by microsurgical viewing, that has transformed our approach to difficult types of retinal detachment, rather than changes in the fundamental processes involved in repair. For the time being, at least, PVR remains the scourge of retinal surgeons and the predominant cause of failure in retinal reattachment surgery. Advances in laser technology and molecular-biological and pharmacological developments should, however, reduce the unwanted effects of excessive proliferation resulting from the healing process and thereby increase the success rate in surgical repair of retinal detachment.

The clinical appearances of advanced PVR are well known. Contraction of epiretinal membranes causes short-

Eye (1994) 8, 210-216 C 1994 Royal College of Ophthalmologists 
ening of the retina, leading to fold formation, while the effect of contraction on retinal breaks is to enlarge them, roll their edges and make them difficult to close. The retinal detachment becomes more extensive and bullous, retinal mobility decreases and the characteristic appearance of a more or less fixed funnel emerges. This is the picture of 'full-blown' PVR, associated with widespread, established epiretinal membranes. There is, however, a spectrum of disease, according to the stage and severity of the proliferative process. Initially, haziness of the vitreous occurs, followed by increasing cellularity, before decreased mobility and the development of fixed retinal folds becomes apparent. Even then, the process may be confined to one or two quadrants of the fundus and the retina may remain attached, and apparently unaffected, in others.

Foos $^{25}$ described a spectrum of non-vascular proliferative extraretinopathies (NPE), passing from simple membranes, composed exclusively of glia, in which the retinal topography remains undisturbed, through intermediate NPE (cellophane maculopathy, macular pucker, surface wrinkling retinopathy) to what is now termed PVR.

To follow the path along which our understanding of PVR has progressed, we need to retrace our steps to the pre-vitrectomy era of the 1950s and 1960s, when PVR was known as massive vitreous retraction (MVR). ${ }^{26}$ Although the presence of membranes on the detached retina had long been recognised, the fundamental pathological process was considered to arise in the vitreous, contraction of which, it was thought, caused the retinal changes. It was therefore widely imagined that removal of the vitreous would lead to successful treatment of complicated retinal detachments. This optimistic belief was rudely shattered in the early 1970s, when the first results of closed vitrectomy in the management of retinal detachments complicated by MVR showed that removing the vitreous was not effective in achieving reattachment in these cases. ${ }^{27}$

The advent of closed intraocular microsurgery, ${ }^{28}$ permitting controlled access to the retinal surface, so that the disease process could be examined directly under the operating microscope, and the harvesting of tissue for histopathological study, was the stimulus to promote much essential research into the cellular mechanisms which cause PVR..$^{29-32}$ A huge leap forward in our understanding of why and how the disease develops has taken place during the past two decades.

Not only has our understanding of the mechanisms and underlying physical forces involved in retinal immobility and shortening been enhanced, but it has been possible to identify the parent cell types and to trace the differentiation of cell lines in the development of epiretinal membranes. It is clear that the simplest membranes are those derived from retinal glia and that these develop commonly, in the absence of true retinal breaks. ${ }^{33}$ They are found in many normal eyes and often cause no clinical signs or symptoms. Glial cells do not have strong con- tractile properties and so, as Foos noted, these simple membranes may cause no retinal distortion at all or only surface wrinkling. ${ }^{33.34}$ In more complex membranes, cells derived from the retinal pigment epithelium (RPE) are common and display strong contractile qualities, causing distortion of the retina, traction on retinal breaks and the formation of full-thickness retinal folds. ${ }^{35-37}$ Furthermore, RPE cells have been shown to develop into macrophages and to form fibroblasts, leading to the development of mature fibrous membranes containing collagen. ${ }^{38}$ It has become clear that, in this way, RPE and glial cells gaining access to the retinal surface, as a result of macroscopic and microscopic breaks in the retina, can form widespread sheets of fibrocellular tissue capable of contracting and thereby shortening it. ${ }^{39.40}$ This process may occur in the attached or reattached retina, as for instance in macular pucker, causing distortion; or contracting membranes may, by opening or reopening retinal breaks, cause retinal detachment or redetachment.

RPE cells can also proliferate in the subretinal space and form membranes, ${ }^{+1-43}$ but contrary to what happens on the inner surface of the retina, these membranes do not form widespread attachments to the retina and display little capacity to cause retinal distortion or shortening. Only occasionally, when such subretinal bands cause a 'washing-line' or 'napkin-ring' effect, ${ }^{4+}$ do they grossly distort the retina or prevent its reattachment.

\section{Classification of PVR}

For clinical purposes, classification of PVR into its various stages or grades is of importance, because without some way of expressing the severity of the disease, it is difficult to evaluate and compare the results of treatment. For this reason, Machemer ${ }^{+1}$ devised a classification based on his concept of its pathogenesis. He identified four stages, ranging from increased vitreous flare and cellularity, to total retinal detachment with a 'closed funnel' configuration. This classification proved unnecessarily complicated and cumbersome and in 1983 a further classification was produced ${ }^{45}$ with four stages: A, B, C and D. A denotes increased vitreous activity, $\mathrm{B}$ the first indications of epiretinal membrane contraction, such as vessel tortuosity and rolled edges to breaks, $\mathrm{C}$ full-thickness fixed retinal folds and $\mathrm{D}$ fixed retinal folds in all quadrants causing a funnel configuration. Grade $\mathrm{C}$ was furthermore subdivided into 1,2 or 3, according to how many quadrants were involved, and D similarly, according to whether the funnel was wide open, narrow or closed.

Both these classifications have been found to be useful in standardising the severity of PVR as identified in different centres, but less useful in providing indices for predicting the likely outcome of surgery. This is because they both fail to take into account the clinical significance of the surgical pathology, depending as it does on the distribution and direction of the tractional forces, rather than simply their extent.

In 1989, workers in Germany ${ }^{46}$ and the United States ${ }^{47}$ proposed new and similar classifications, leading to a bet- 
ter scheme which acknowledges the surgical implications of PVR. This classification, updated in 1991 , $^{48}$ distinguishes between peripheral and posterior, focal and diffuse and perpendicular, circumferential and anterior forms of contraction, enabling comparability of results from different centres.

\section{TREATMENT}

Retinal detachments complicated by PVR are difficult to treat, because the surface area of the retina is reduced, due to membrane contraction, so the retina cannot easily be reapplied to the underlying pigment epithelium, the surface area of which is unaltered. Retinal breaks, which are the cause of the detachment, cannot be closed by conventional means unless the breaks themselves are in an area of retina not involved by contracted membranes. In some instances this is the case and, in spite of PVR, the retina can be reattached by conventional surgery. Provided that all breaks are closed and remain closed, the retina will invariably reattach, although there may be gross distortion from epiretinal membrane contraction throughout the fundus elsewhere, causing areas of traction retinal detachment. As in all retinal reattachment surgery, the goal is to close the breaks and seal them.

\section{Surgical Methods}

Long before Machemer and Norton ${ }^{27}$ demonstrated that removal of the vitreous was not sufficient, in itself, to cure retinal detachments complicated by PVR, Taylor Smith, Cibis and others had appreciated the significance of epiretinal membrane contraction and come to similar conclusions. Indeed, Taylor Smith, ${ }^{49}$ writing in 1960, described their role in causing fixed retinal folds and recalled that, since the nineteenth century, many workers had noted the presence of epiretinal membranes on the surface of the detached retina, while Cibis ${ }^{50}$ described how epiretinal membranes could be removed from the retinal surface, albeit without the degree of access provided by techniques available today. The use of silicone oil and intraocular instrumentation to dissect membranes and to tamponade breaks was used to good effect by Cibis, ${ }^{51}$ $\mathrm{Scott}^{52}$ and others, ${ }^{53}$ prior to the introduction of closed intraocular microsurgery, up to $60 \%$ of such cases being successful.

The introduction of vitrectomy ${ }^{28}$ led the way to more sophisticated methods of epiretinal membrane removal which, combined with internal tamponade of retinal breaks, opened up new avenues. While removal of the vitreous does not, in itself, relieve anything except direct vitreoretinal traction, the controlled access to and freedom of action within the preretinal space which it enables, has transformed the surgery of PVR.

It was soon apparent that the application of closed vitrectomy techniques could be combined with and enhance existing methods of treating retinal conditions characterised by the proliferation and contraction of fibrocellular (and fibrovascular) membranes. ${ }^{5+59}$ Bimanual manoeuvres, carried out under greatly improved condi- tions of illumination and microscopy and with an everincreasing range of sophisticated micro-instrumentation, ${ }^{60.61}$ brought the treatment of complicated cases of retinal detachment within the compass of many retinal surgeons, rather than the exceptional few. By direct removal of membranes responsible for retinal shortening, the retina can be mobilised and retinal breaks freed of traction, before filling the preretinal compartment with air, gas or silicone fluid. Moreover, it is no longer necessary to go through the coats of the globe to drain subretinal fluid, as this can be done safely, via a flute-needle passed through a break in the retina, using the operating microscope. Many of these considerations apply equally to fibrovascular as well as to fibrocellular membranes; however, only nonvascular disease will be discussed here.

Removal of the vitreous gel is the simplest part of surgery for retinal detachments complicated by PVR. Once the gel has been carefully removed, it is possible to gain access to all areas of the retina and it is important to remove the gel meticulously, up to its retinal attachment at the vitreous base. Mobilisation of the retina requires that all epiretinal membranes are stripped from its surface behind the base. This can be achieved using a 20 gauge needle, bent to form a pic; in PVR it is rarely necessary to use scissors, posterior to the vitreous base, because, unlike fibrovascular proliferations, fibrocellular membranes can be pecled and do not usually require segmentation or delamination.

The vitreous at the vitreous base itself cannot be removed from the retina and retinal shortening at or anterior to it must therefore be managed in different ways. If contraction is only mild or moderate, a scleral buckle will usually suffice to reappose the retina to the RPE, but if vitreous base shortening is severe, one of two methods must be adopted: (1) complete removal of all epiretinal tissue by meticulous dissection, including cutting the retina radially where necessary, followed by a deep, broad buckle and extensive laser photocoagulation, ${ }^{62}$ or (2) division of the retina, in a circumferential direction, immediately posterior to the shortened base, ${ }^{63,6+}$ throughout at least $180^{\circ}$ (separating the shortened anterior retina from the mobile retina posterior to the vitreous base), followed by laser photocoagulation to the cut edge of the posterior flap, after tamponade with gas or silicone oil.

Excellent results have been reported, ${ }^{65}$ in anterior PVR, using the first of these two options, especially by those using gas rather than silicone oil tamponade, but the dissection can take 4-8 hours to accomplish. The second method is more practicable and good results have also been reported, ${ }^{66-68}$ removal of epiretinal membranes being limited to the posterior retina and care taken to excise the tissue anterior to the retinotomy to discourage the development of cyclitic membranes and rubeosis.

In cases where PVR is further complicated by the coexistence of a giant tear or giant retinotomy, causing destabilisation of the posterior flap, it is occasionally necessary to use retinal tacks to stabilise the retina. Tacks (introduced by Ando $^{69}$ in 1983) are used as an adjunct to tampo- 
nade and endolaser photocoagulation and not as a substitute.

More recently, liquid perfluorocarbons have been introduced by Chang and co-workers. ${ }^{70.71}$ These agents have a specific gravity greater than 1.5 , low viscosity and moderate surface tension in aqueous fluids. Their density makes it possible to 'roll out' the detached retina posteriorly and displace the subretinal fluid laterally and anteriorly. Dissection of epiretinal membranes is facilitated and subretinal fluid can be displaced through anterior breaks into the preretinal space from where it can be removed easily.

\section{Internal Tamponade}

Internal tamponade with air has been used in the treatment of complicated retinal detachments for more than 80 years, ${ }^{72}$ while Rosengren ${ }^{73}$ in 1938 reported a series of more than 300 cases treated in this way. The method became less popular with the introduction of scleral explants by Custodis, ${ }^{74}$ and it was not until 1973 that Norton $^{75}$ popularised the use of air and less soluble, inert gases such as sulphur hexafluoride in the treatment of selected cases. In the early $1960 \mathrm{~s}$, Cibis $^{51}$ began to use silicone oil for prolonged tamponade, the use of this material being popularised and developed by Scott, ${ }^{76}$ Zivojnovic $^{77}$ and others. $^{44,78}$

It has already been noted that vitrectomy enables the removal of epiretinal membranes and thereby facilitates retinal reattachment by internal fluid exchange through the retinal breaks. Air and gases are ideal materials for tamponading breaks, because of their high surface tension in aqueous fluids and their buoyancy. The duration of tamponade can be varied according to the type of gas chosen, the long-chain perfluorocarbon gases such as perfluoropropane remaining effective for up to 6 weeks. Nevertheless, as the gas is absorbed, the bubble gets smaller and tamponade becomes less reliable. By contrast, silicone oil has a lower surface tension in aqueous fluids and less buoyancy but remains in the eye indefinitely, so that its effect is constant. Arguments for and against the use of these agents centre largely around complications associated with their use, ${ }^{79}$ while the results of recent studies suggest that there is no significant difference in efficacy between silicone oil and the longer-acting gases. ${ }^{80,81}$

There is little doubt that the results of treating retinal detachments complicated by PVR have improved since the development of techniques combining vitrectomy with internal tamponade and that prolonged tamponade, whether by long-acting gases or silicone oil, conveys significant benefits. Furthermore, much of the resistance to the use of silicone oil has been overcome by the knowledge that it can be easily removed when tamponade is no longer needed, ${ }^{68,82-85}$ thus pre-empting development of long-term complications.

\section{Prevention}

It is now generally accepted that RPE cells and glia are the cells responsible for $\mathrm{PVR}^{86,87}$ and that agents such as fibronectin, ${ }^{88-92}$ platelet-derived growth factor ${ }^{93.94}$ and transfor- ming growth factor beta, ${ }^{95-97}$ stimulate and promote the proliferation, migration and contraction of these cells. The cells, in their turn, form extracellular matrix and finally collagen. $^{98}$ This chain of events is exacerbated by breakdown of the blood-ocular barrier. ${ }^{99}$

Could the process be stopped at any point, it might be possible to prevent or arrest the development of epiretinal membranes causing complicated retinal detachments. To this end, efforts have been made to assess the influence of anti-inflammatory agents such as corticosteroids, ${ }^{100-102}$ anti-proliferatives such as 5-fluorouracil ${ }^{103,104}$ and daunomycin, ${ }^{102,105}$ low-dose irradiation, ${ }^{106,107}$ and agents such as heparin ${ }^{108}$ acting on the extracellular components, on the development of PVR. While experimental evidence suggests that they all influence the proliferative process ${ }^{109}$ and their trial in animal models of PVR and even in human eyes has shown encouraging trends, ${ }^{110}$ no agent or combination of drugs has been demonstrated to be of incontrovertible benefit in clinical management. This may be because the development of PVR in the clinical arena is usually well established before the drugs are used, unlike the experimental situation where they may be delivered at the outset of the process.

\section{CONCLUSION}

Our understanding of the pathophysiology of PVR has been greatly enhanced as a result of closed microsurgical methods. Conversely, the development of modern surgical techniques has been influenced and guided by a better understanding of the underlying disease process. The development of PVR and its prevention depends on the quality of primary retinal reattachment surgery. Accurate identification of all retinal breaks, leading to their successful closure at the first attempt, would preclude the onset of PVR in the majority of cases, while improved techniques, causing less inflammation, reduced risk of haemorrhage and other stimuli to cellular proliferation, would contribute positively towards this end. Ultimately, however, the elimination or reduction of PVR is likely to result from advances in our understanding of molecular biology and pharmacology, rather than from changes in surgical method.

Key words: Epiretinal membranes, Proliferative vitreoretinopathy, Retina, Vitrectomy, Vitreoretinal.

\section{REFERENCES}

1. Gonin J. La pathogénie du décollement spontané de la retine. Ann d'Oculist (Paris) 1904;132:30.

2. Gonin J. Le traitement du décollement retinien. Ann d'Oculist (Paris) 1921;158:175.

3. Guist G. Eine neue Ablatiooperation. Z Augenheilkd 1931; $74: 232$.

4. Lindner K. Eine Beitrag zur Entstheung und Behandlung der idiopathischen und der traumatischen Netzhautabhebung. Arch Ophthalmol 1931;127:177.

5. Kasner D, Miller GR, Taylor WH, et al. Surgical treatment of amyloidosis of the vitreous. Trans Am Acad Ophthalmol Otolaryngol 1968;72:410.

6. Machemer R, Parel JM, Buettner H. A new concept for vitreous surgery. I. Instrumentation. Am J Ophthalmol 1972; 73:1. 
7. McCuen BW, Hida T, Sheta SM, et al. Experimental transvitreal cyanoacrylate retinopexy. Am J Ophthalmol 1986; 102:199.

8. Gilbert CE. Adhesives in retinal detachment surgery. Br J Ophthalmol 1991;75:309.

9. Gilbert CE, Grierson I, McLeod D. Retinal patching: a new approach to the management of selected retinal breaks. Eye 1989;3:19.

10. Gonin J. Guérisons operatoires de décollement retiniens. Rev Gen Ophthalmol 1923;337:37.

11. Pischell DK. Diathermy operation for retinal detachment: comparative results of different types of electrodes. Trans Am Ophthalmol 1944;42:543.

12. Lincoff HA, McLean JM, Nano H. Cryosurgical treatment of retinal detachment. Trans Am Acad Ophthalmol Otolaryngol 1964;68:412.

13. Meyer-Schwickerath G. Koagulation der Netzhaut mit Sonnenlicht. Ber Dtsch Ophthalmol Ges 1949;55:256.

14. L'Esperance FA. An ophthalmic argon photocoagulation laser system: design, construction, and laboratory investigations. Trans Am Ophthalmol Soc 1968;66:827.

15. Little HL, Zweng HC, Peabody RR. Argon laser slitlamp retinal photocoagulation. Trans Am Acad Ophthalmol Otolaryngol 1970;74:85.

16. Lindner K. Heilungsversuche bei prognostisch ungunstigen Fallen von Netzhautabhebung. Z Augenheilkd 1933; 81:227.

17. Arruga $\mathrm{H}$. Le cerclage equatorial pour traiter le décollement retinien. Bull Mem Soc Fr Ophthalmol 1958;71:571.

18. Lincoff HA, Baras I, McLean J. Modifications to the Custodis procedure for retinal detachment. Arch Ophthalmol 1965;73:160.

19. Schepens CL, Okamura ID, Brockhurst RJ. The scleral buckling procedures. V. Synthetic sutures and silicone implants. Arch Ophthalmol 1960;64:868.

20. Laqua $H$, Machemer R. Glial cell proliferation in retinal detachment (massive periretinal proliferation). Am J Ophthalmol 1975;80:602.

21. Kenyon KR, Michels RG. Ultrastructure of epiretinal membrane removed by pars plana vitreoretinal surgery. Am J Ophthalmol 1977;83:815.

22. Hiscott PS, Grierson I, Trombetta CJ, et al. Retinal and epiretinal glia: an immunohistochemical study. $\mathrm{Br} \mathrm{J}$ Ophthalmol 1984;68:698.

23. Van Horn DL, Aaberg TM, Machemer R et al. Glial cell proliferation in human retinal detachment with massive periretinal proliferation. Am J Ophthalmol 1977;84:383.

24. Glaser BM, Sjaarda RN, Kuppermann BD et al. Transforming growth factor-beta in the treatment of full thickness macular holes. Ophthalmology 1991;98(Suppl):145.

25. Foos RY. The spectrum of nonvascular proliferative extraretinopathies. In: Nicholson, editor. Ocular pathology update. Los Angeles, 1980:107.

26. Schepens CL. Retinal detachment and aphakia. Arch Ophthalmol 1951;45:1.

27. Machemer R, Norton EWD. A new concept for vitreous surgery. III. Indications and results. Am J Ophthalmol 1972;74:1034.

28. Machemer R, Buettner H, Norton EWD, Parel JM. Vitrectomy: a pars plana approach. Trans Am Acad Ophthalmol Otolaryngol 1971;75:813.

29. Smith RS, van Heuven WAJ, Streeten B. Vitreous membranes: a light and electron microscopic study. Arch Ophthalmol 1976;94:1556.

30. Clarkson JG, Green WR, Massof D. A histopathologic review of 168 cases of preretinal membrane. Am J Ophthalmol 1977;84:1.

31. Kampik A, Kenyon KR, Michels RG, Green WR, de la Cruz ZC. Epiretinal and vitreous membranes: comparative study of 56 cases. Arch Ophthalmol 1981;99:1445.
32. Grierson I, Rahi AHS. Structural basis of contraction in vitreal fibrous membranes. Br J Ophthalmol 1981;65:737.

33. Roth AM, Foos RY. Surface wrinkling retinopathy in eyes enucleated at autopsy. Trans Am Acad Ophthalmol Otolaryngol 1971;75:1047.

34. Foos RY. Surface wrinkling retinopathy. In: Freeman HM, Hirose T, Schepens CL, editors. Vitreous surgery and advances in fundus diagnosis and treatment. New York: Appleton Century Crofts, 1977:23.

35. Machemer R, Laqua H. Pigment epithelium proliferation in retinal detachment (massive periretinal proliferation). Am J Ophthalmol 1975;80:1.

36. Clarkson JG, Green WR, Massof D. A histopathological review of 168 cases of preretinal membrane. Am J Ophthalmol 1977;84:1.

37. Laqua H, Machemer R. Clinical-pathological correlation in massive periretinal proliferation. Am J Ophthalmol 1975;80:913.

38. Newsome DA, Rodrigues MM, Machemer R. Human massive periretinal proliferations: in vitro characteristics of cellular components. Arch Ophthalmol 1981;99:873.

39. Laqua H, Machemer R. Glial cell proliferation in retinal detachment (massive periretinal proliferation). Am J Ophthalmol 1975;80:602.

40. Algvere P, Kock E. Experimental epiretinal membranes induced by intravitreal carbon particles. Am J Ophthalmol 1983;96:345.

41. Machemer R. Pathogenesis and classification of massive periretinal proliferation. Br J Ophthalmol 1978;62:737.

42. Sternberg P, Machemer R. Subretinal proliferation. Am J Ophthalmol 1984;98:456.

43. Schwartz D, de la Cruz Z, Green WR, et al. Proliferative vitreoretinopathy: ultrastructural study of 20 retroretinal membranes removed by vitreous surgery. Retina 1988;8: 275.

44. Charles S. Vitreous microsurgery, 1st ed. Baltimore: Williams and Wilkins, 1981.

45. The Retina Society Terminology Committee. The classification of retinal detachment with proliferative vitreoretinopathy. Ophthalmology 1983;90:121.

46. Heimann K, Wiedemann P. Cologne classification of proliferative vitreoretinopathy. In: Heimann K, Wiedemann P, editors. Proliferative vitreoretinopathy. Heidelberg: Kaden Verlag, 1989:148.

47. Irvine AR, Lean JS, Stern WH. Classification and photographic documentation of PVR. In: Heimann K, Wiedemann P, editors. Proliferative vitreoretinopathy. Heidelberg: Kaden Verlag, 1989:144.

48. Machemer R, Aaberg TM, Mackenzie Freeman H et al. An updated classification of retinal detachment with proliferative vitreoretinopathy. Am J Ophthalmol 1991;112:159.

49. Smith TR. Pathological findings after retina surgery. In: Schepens S, editor. Importance of vitreal body in retinal surgery with special emphasis on reoperation. St Louis: CV Mosby, 1960:61.

50. Cibis PA. Vitreoretinal pathology and surgery in retinal detachment. St Louis: CV Mosby, 1965.

51. Cibis PA. Recent methods in the surgical treatment of retinal detachment: intravitreal procedures. Trans Ophthalmol Soc UK 1965;85:111.

52. Scott JD. Treatment of the detached immobile retina. Trans Ophthalmol Soc UK 1972;92:351.

53. Grey RHB, Leaver PK. Silicone oil in the treatment of massive preretinal retraction. I. Results in 105 eyes. Br J Ophthalmol 1979;63:355.

54. Parel JM, Machemer R, Aumayr W. A new concept for vitreous surgery. IV. Improvements in instrumentation and illumination. Am J Ophthalmol 1974;77:6.

55. O’Malley C, Heintz RM. Vitreotomy with an alternative instrument system. Ann Ophthalmol 1975;7:585. 
56. Charles S. Fluid-gas exchange in the vitreous cavity. Ocutome/Fragmatome Newsletter 1977;2:1.

57. Aaberg TM, Machemer R. Vitreous band surgery: instrumentation and technique. Arch Ophthalmol 1972;87:542.

58. Lean JS, Leaver PK, Cooling RJ et al. Management of complex retinal detachments by vitrectomy and fluid/silicone exchange. Trans Ophthalmol Soc UK 1982;102:203.

59. Machemer R. Surgical approaches to subretinal strands. Am J Ophthalmol 1980;90:81.

60. Michels RG, Rice TA, Ober RR. Vitreoretinal dissection instruments. Am J Ophthalmol 1979;87:836.

61. Courvillion GC. Vitreous surgery instrumentation. In: Freeman HM, Hirose T, Schepens CL, editors. Vitreous surgery and advances in fundus diagnosis and treatment. New York: Appleton Century Crofts, 1977:165.

62. Aaberg TM. Management of anterior and posterior proliferative vitreoretinopathy. XLV Edward Jackson Memorial Lecture. Am J Ophthalmol 1988;106:519.

63. Machemer R, McCuen BW, de Juan E. Relaxing retinotomies and retinectomies. Am J Ophthalmol 1986;102:7.

64. Jacobs PM, Cooling RJ, Leaver PK, McLeod D. Retinal relieving incisions. Eye 1987;1:500.

65. Lewis H, Aaberg TM, Abrams GW. Causes of failure after initial vitreoretinal surgery for severe proliferative vitreoretinopathy. Am J Ophthalmol 1991;111:8.

66. Reinking U, Lucke K, Bopp S, Laqua H. Results after retinotomy and retinectomy in the treatment of complicated retinal detachment. Klin Monatsbl Augenheilkd 1990;197: 382.

67. Iverson DA, Ward TG, Blumenkranz MS. Indications and results of relaxing retinotomy. Ophthalmology 1990;97: 1298 .

68. Eckardt C, Behrendt S, Zwick A. Results of silicone oil removal from eyes treated with retinectomies. German $\mathbf{J}$ Ophthalmol 1991;1:2.

69. Ando F, Kondo J . A plastic tack for the treatment of retinal detachment with giant tear. Am J Ophthalmol 1983;95: 260.

70. Chang S. Low viscosity liquid fluorochemicals in vitreous surgery. Am J Ophthalmol 1987;103:38.

71. Chang S, Ozmert E, Zimmerman NJ. Intraoperative perfluorocarbon liquids in the management of proliferative vitreoretinopathy. Am J Ophthalmol 1988;106:668.

72. Ohm J. Über die Behandlung der Netzhautablosung durch operative Entleerung der subretinalen Flussigkeit und Einspiritzung von Luft in der Glaskorper. Arch Ophthalmol 1911;79:442.

73. Rosengren B. Über die Behandlung der Netzhautablosung mittelst Diathermie und Luftinjektion in den Glaskörper. Acta Ophthalmol (Copenh) 1938;16:3.

74. Custodis E. Bedeutet die Plombenaufnahung auf die Sklera einen Fortschritt in der operativen Behandlung der Netzhautablosung? Ber Dtsch Ophthalmol Ges 1953;58:102.

75. Norton EWD. Intraocular gas in the management of selected retinal detachments. Trans Am Acad Ophthalmol Otolaryngol 1973;77:85.

76. Scott JD. The treatment of massive vitreous retraction. Trans Ophthalmol Soc 1973;93:417.

77. Zivojnovic R, Mertens DAE, Peperkamp E. Das flüssige Silikon in der Amotiochirugie. II. Bericht über 280 falleweitere Entwicklung der Technik. Klin Monatsbl Augenheilkd 1982;181:444.

78. Lucke KH, Foerster MH, Laqua H. Long-term results of vitrectomy and silicone oil in 500 cases of complicated retinal detachments. Am J Ophthalmol 1987;104:624.

79. Leaver PK. Complications of intraocular silicone oil. In: Ryan SJ, editor. Retina, vol. 3. St Louis: CV Mosby, 1989: 293.

80. Silicone Oil Study Report 1. Vitrectomy with silicone oil or sulphur hexafluoride gas in eyes with severe proliferative vitreoretinopathy. Results of a randomized clinical trial. Arch Ophthalmol 1992;110:770.

81. Silicone Oil Study Report 2. Vitrectomy with silicone oil or perfluoropropane gas in eyes with severe proliferative vitreoretinopathy. Results of a randomized clinical trial. Arch Ophthalmol 1992;110:780.

82. Gonvers M. Temporary silicone oil tamponade in the management of retinal detachment with proliferative vitreoretinopathy. Am J Ophthalmol 1985;100:239.

83. Casswell AG, Gregor ZG. Silicone oil removal. I. The effect on the complications of silicone oil. Br J Ophthalmol 1987;71:893.

84. Hoing C, Kampik A, Heidenkummer HP. Possibilities of silicone oil removal after complex vitreoretinal surgery. Fortschr Ophthalmol 1991;8:593.

85. Franks WA, Leaver PK. Removal of silicone oil: rewards and penalties. Eye 1991;5:333.

86. Hiscott PS, Grierson I, Hitchins CA et al. Epiretinal membranes in vitro. Trans Ophthalmol Soc UK 1983;103:89.

87. Hiscott PS, Grierson I, McLeod D. Natural history of fibrocellular epiretinal membranes: a quantitative, autoradiographic, and immunohistochemical study. Br J Ophthalmol 1985;69:810.

88. Weller M, Heimann K, Wiedemann P. Immunohistochemical findings in proliferative retinal diseases: on the significance of fibronectin, macrophages and transferrin. Fortschr Ophthalmol 1989;86:121.

89. Weller M, Wiedemann P, Bresgen M, Heimann K. Vitronectin: mediator of cell adhesion in proliferative vitreoretinopathy? Fortschr Ophthalmol 1990;87:221.

90. Hiscott P, Walker HA, Grierson I, et al. Local production of fibronectin by ectopic human retinal cells. Cell Tissue Res 1992;267:185.

91. Wilson-Holt N, Khaw P, Savage F, Grierson I. The chemoattractant activity of the vitreous to human scleral fibroblasts following retinal detachment and proliferative vitreoretinopathy. Br J Ophthalmol 1992;76:159.

92. Campochiaro PA, Jerdan JA, Glaser BM. Serum contains chemoattractants for human retinal pigment epithelial cells. Arch Ophthalmol 1984;102:1830.

93. Campochiaro PA, Glaser BM. Platelet-derived growth factor is chemotactic for human retinal pigment epithelial cells. Arch Ophthalmol 1985;103:576.

94. Pinon RM, Pastor JC, Saornil MA et al. Intravitreal and subretinal proliferation induced by platelet-rich plasma injection in rabbits. Curr Eye Res 1992;11:1047.

95. Connor TB, Roberts AB, Sporn MB et al. Correlation of fibrosis and transforming growth factor-beta type 2 levels in the eye. J Clin Invest 1989;83:1661.

96. Gaudric A, Glacet-Bernard A, Clement G et al. Transforming growth factor-beta in the vitreous of patients with epiretinal proliferation. Ophtalmologie 1990;4:51.

97. Wiedemann P. Growth factors in retinal disease: proliferative vitreoretinopathy, proliferative diabetic retinopathy, and retinal degeneration. Surv Ophthalmol 1992;35:373.

98. Campochiaro PA, Jerdan JA, Glaser BM. The extracellular matrix of human retinal pigment epithelial cells in vivo and its synthesis in vitro. Invest Ophthalmol Vis Sci 1986;27: 1615.

99. Clausen R, Weller M, Hilgers RD et al. Quantitative determination of 5 vitreal proteins in the normal vitreous body and proliferative retinal diseases. Fortschr Ophthalmol 1990;87:283.

100. Tano Y, Chandler D, Machemer R. Treatment of intraocular proliferation with intravitreal injection of triamcinolone acetonide. Am J Ophthalmol 1980;90:810.

101. Chandler DB, Hida T, Sheta S et al. Improvement in efficacy of corticosteroid therapy in an animal model of proliferative vitreoretinopathy by pretreatment. Graefes Arch Clin Exp Ophthalmol 1987;225:259. 
102. Hui YN, Liang HC, Cai YS et al. Corticosteroids and daunomycin in the prevention of experimental proliferative vitreoretinopathy induced by macrophages. Graefes Arch Clin Exp Ophthalmol 1993;231:109.

103. Blumenkranz MS, Ophir A, Clafin AJ et al. Fluorouracil for the treatment of massive periretinal proliferation. Am J Ophthalmol 1982;94:458.

104. Blumenkranz MS, Hernandez E, Ophir A et al. 5-Fluorouracil: new applications in complicated retinal detachment for an established antimetabolite. Ophthalmology 1984;91:122.

105. Wiedemann P, Lemmen K, Schmiedl R, Heimann K. Intraocular daunorubicin for the treatment and prophylaxis of traumatic proliferative vitreoretinopathy. Am J Ophthalmol 1987; 104:10.

106. Binder S, Skorpic CH, Paroussis $\mathrm{P}$ et al. High-energy elec- trons used to inhibit experimental intraocular proliferation and detachment. Ophthalmologica 1987;195:128.

107. Kuriyama S, Ohuchi T, Yoshimura N, et al. Evaluation of radiation therapy for experimental proliferative vitreoretinopathy in rabbits. Graefes Arch Clin Exp Ophthalmol 1990;228:552.

108. Alvira G, Hartzer M, Blumenkranz MS. Heparin inhibits cell-mediated collagen gel contraction. Invest Ophthalmol Vis Sci 1986;27:305.

109. Blumenkranz MS, Clafin A, Hajek AS. Selection of therapeutic agents for intraocular proliferative disease: cell culture evaluation. Arch Ophthalmol 1984;102:598.

110. Radtke ND, Weinsieder AD, Ballou RJ. Pharmacological therapy for proliferative vitreoretinopathy. Graefes Arch Clin Exp Ophthalmol 1986;224:230. 